\title{
Effect of zeolite and urea fertilizer on maize grown under saline conditions
}

\author{
M. Aboul-Magd, K. A. Elzopy and Z. R. M. Zangana
}

Soil and Agric. Chemistry Dept., Faculty of Agriculture (Saba Basha) Alexandria University, Egypt Received: 19 Nov. 2019 / Accepted 22 Dec. 2019 / Publication date: 25 Jan. 2020

\begin{abstract}
Saline soil is one of the major abiotic stresses that minify plant growth and crop productivity in arid and semiarid regions. A pot experiment was conducted during the summer season of 2019 to evaluate the effect of zeolite and urea fertilizer on growth and yield of maize grown under saline conditions. The experiment design was Factorial RCBD with four replicates, the first factor was zeolite level $\{0$ (control), 2, 4 and $6 \%\}$ and the second factor was urea fertilizer level $\{0$ (control), 30, 60 and $90 \mathrm{~kg} \mathrm{~N} / \mathrm{fed}\}$. Results showed a significant increase in the vegetative growth characteristics of maize i.e. plant height, fresh and dry weight, total chlorophyll (SPAD), and leaf area under zeolite application treatments as compared with control ( $0 \%$ zeolite). Among the studied zeolite rates, $6 \%$ zeolite treatment resulted the highest vegetative growth parameters. Moreover, the application of urea fertilizer at $90 \mathrm{~kg}$ $\mathrm{N} /$ fed recorded the highest values of vegetative growth parameters, as compared with untreated treatment (control) which gave the lowest values of these traits. Zeolite application also enhanced plant NPK content and soil available NPK as compared with the untreated soil. The highest plant NPK content and soil available NPK were recorded under $6 \%$ zeolite rate. Similarly, application of $90 \mathrm{~kg} \mathrm{~N} / \mathrm{fed}$ of urea fertilizer produced the highest plant NPK content and soil available NPK as compared with control. These results revealed that zeolite amendment mitigated salt stress, improved plant growth, and enhanced absorbing nutrients by plant and retaining nutrients in soil. The results concluded that zeolite amendment can be an efficient tool to increase crop productivity and food production, reduce nutrient losses and environmental pollution, and to expand the agricultural utilization of the low-quality soil in arid and semi-arid regions.
\end{abstract}

Keywords: maize, salts affected, zeolite, urea fertilizer, vegetative growth, chemical composition.

\section{Introduction}

Maize (Zea mays L.) is one of the most important cereal crop of world and third most important crop after rice and wheat. It requires good agronomic practices for improvement in yield as it is very sensitive to nutrient status of soil (Suriyaprabha et al., 2014).

Maize is one of the most important cereals in the world. The productive potential of this crop is closely associated with nitrogen $(\mathrm{N})$ fertilization, thus, studies focused on this subject are important in the development of cropping strategies (Oliveira et al., 2017).

Salinity is one of the most alarming abiotic stress affecting crop productivity and significant crop loss globally. It impedes plant performance by inducing deleterious effects on germination and plant vigor. Moreover, $6 \%$ of total land area and 30\% in irrigated lands are affected by salinity (Fahad et al., 2014).

Excessive uses of fertilizer can create environmental problems such as soil pollution. This problem could be reduced by amending clinoptilolite zeolite with compound fertilizers (Lija et al., 2014).

In an agricultural field, it was reported that soil amendment with zeolite reduces the impact of saline water on barley plant due to the capability of zeolite for enhancing water and salt holding capacity of soil (Al-Busaidi et al., 2008). Jakab and Jakab (2010) used grinded zeolite tuff with different doses for amendment of soil at depths of 20-25 cm under furrow.

Soil zeolite application decreased antioxidant enzymes activity. It seems that zeolite increases water retention capacity and thus water stress intensity will be decreased (Zahedi and TohidiMoghadam 2011).

Ghanbari and Ariafar, (2013) indicates that natural zeolite may represent an important alternative to reduce the effects of drought in arid and semi-arid regions. It can be used to improve the soils, boost the effects of chemical and organic fertilizers-alike, and as a component of substratum for the development of different crops (Najafi-Ghiri, 2014).

Corresponding Author: Hussein M.A.K., Soil and Agric. Chemistry Dept. Faculty of Agriculture (Saba Basha) Alexandria University, Egypt. 
Zeolite improves physical properties such as water conductivity, ventilation and soil moisture, as well as mitigating soil erosion caused by surface runoff, reducing the speed of running, reducing soil loss, and improving degraded pastures (Behzadfar et al., 2017).

Zeolites are minerals characterized by high cation exchange capacity (CEC) (Ramos et al., 2018).

Urea $\left[\mathrm{CO}\left(\mathrm{NH}_{2}\right)_{2}\right]$ is the main nitrogen fertilizer used in agriculture, accounting for $60 \%$ of the commercialized $\mathrm{N}$ fertilizers worldwide (Heffer and Prud'homme, 2015). However, the main concern for agricultural use of this fertilizer is its high $\mathrm{N}$ losses through ammonia $\left(\mathrm{NH}_{3}\right)$ volatilization when applied on soil surface, after the hydrolysis reaction catalyzed by urease enzyme (Chien et al., 2009).

Urease activity is the greatest regulator of $\mathrm{NH}_{3}$ volatilization, and it can be inhibited by complexing the enzyme with small molecules or with specific ions during the fertilizer formulation. Thus, urease inhibitors like N-(n-butyl) thiophosphoric triamide (NBPT), copper $\left(\mathrm{Cu}^{+2}\right)$ and boric acid $\left(\mathrm{H}_{3} \mathrm{BO}_{3}\right)$, as well as polymers and elemental sulphur that interfere with solubilization, have been studied to reduce N losses by volatilization (Du et al., 2008; Trenkel, 2010; Soares et al., 2012; Nascimento et al., 2013).

Moreover, clay minerals of the zeolite group are currently being tested with the same objective. These clay minerals present some cation exchange capacity (CEC), which is responsible for $\mathrm{NH}_{4}{ }^{+}$ retention in the soil and for its gradual release to the soil solution (Calvo et al., 2009). According to Bernardi et al. (2007), urea mixtures with $25 \%$ of zeolite improved $\mathrm{N}$ use by plants, especially with higher application rates.

The objective of this study was to determine the evaluating the effect of zeolite on urea fertilizer use efficiency and some properties of on growth and chemical composition of maize grown under salts affected soil conditions.

\section{Materials and Methods}

Pots experiments were conducted on maize at the Experimental green house of Faculty Agriculture (Saba-Basha), Alexandria University, Egypt, during the growing season of 2019 to evaluate the impact of zeolite on urea fertilizer use efficiency and some properties of salt affected soil. The soil physical and chemical properties were determined according to the methods described by Jackson (1973). The obtained results were presented in (Table 1).

\section{Type of soil}

Soil texture was sandy clay loam soil. A surface sample $(0-30 \mathrm{~cm})$ was collected before planting to identify some physical and chemical properties of this soil as shown in Table (1).

Table 1: Some soil properties of the tested soil

\begin{tabular}{|c|c|c|}
\hline Parameters & Value & Unit \\
\hline \multicolumn{3}{|l|}{ Particle size distribution } \\
\hline Sand & 76.22 & $\%$ \\
\hline Silt & 14.30 & $\%$ \\
\hline Clay & 9.48 & $\%$ \\
\hline Soil texture & \multicolumn{2}{|c|}{ Sandy clay loam } \\
\hline Organic matter content & 0.38 & $\%$ \\
\hline Soil PH & 8.18 & - \\
\hline Electric conductivity (EC) & 5.30 & $\mathrm{dS} / \mathrm{m}$ \\
\hline $\mathrm{CaCO}_{3}^{-}$ & 38.9 & $\%$ \\
\hline \multicolumn{3}{|l|}{ Available macronutrient } \\
\hline $\mathbf{N}$ & 11.34 & $\mathrm{mg} / \mathrm{kg}$ soil \\
\hline $\mathbf{P}$ & 22.00 & $\mathrm{mg} / \mathrm{kg}$ soil \\
\hline $\mathbf{K}$ & 250.00 & $\mathrm{mg} / \mathrm{kg}$ soil \\
\hline \multicolumn{3}{|l|}{ Available micronutrient } \\
\hline $\mathrm{Ca}^{++}$ & 16.4 & meq. / L \\
\hline $\mathbf{M g}^{++}$ & 9.84 & meq. / L \\
\hline $\mathbf{N a}^{+}$ & 6.34 & meq. / L \\
\hline $\mathbf{K}^{+}$ & 3.10 & meq. / L \\
\hline \multicolumn{3}{|l|}{ Soluble Anions } \\
\hline $\mathrm{HCo}_{3}^{-}$ & 1.20 & meq. / L \\
\hline Cl & 10.2 & meq. / L \\
\hline $\mathrm{SO}_{4}^{--}$ & 52.80 & meq. / L \\
\hline
\end{tabular}




\section{Experimental Design}

The experimental design was completely randomized block design (Factorial RCBD) with four replicates, with 16 treatments with four replicates where the four zeolite levels $(0,80,160$ and 240g/pot) were arranged in the main plots, whereas, the four urea fertilizer (control, 2, 4 and $6 \mathrm{~g} /$ pot) were arranged in the sub plots, were planted on $2^{\text {th }}$ of June in the seasons (2019).

The experimental treatments can be described as follows:

A) Main plots (zeolite levels)

- 0

- $2 \%$

- $4 \%$

- $6 \%$

B) Sub-plots (urea fertilizer)

- Control

- $30 \mathrm{~kg} / \mathrm{fed}$.

- $60 \mathrm{~kg} / \mathrm{fed}$.

- $90 \mathrm{~kg} / \mathrm{fed}$.

\section{Studied characteristics}

A) Vegetative growth

- Plant height $(\mathrm{cm})$

- Total fresh weight (g)

- Total dry weight (g)

- Leaf area index (LAI).

- Total chlorophyll (SAPD).

\section{B) Chemical composition in leaves:}

The NPK percentages were determined in the dry leaves. Their dry weights were determined following drying in a drying chamber to a constant weight at $75^{\circ} \mathrm{C}$ for 72 hour according to Tandon (1995). After dryness, the plant samples were milled and stored for analysis as reported. However, $0.5 \mathrm{~g}$ of the leaves powder was wet-digested with $\mathrm{H}_{2} \mathrm{SO}_{4}-\mathrm{H}_{2} \mathrm{O}_{2}$ mixture according (Lowther, 1980) and the following determinations were carried out in the digested solution to determine the following:

After drying, leaves were grounds to a fine powder by using a mortar and pestle. Concentrations of the following minerals nitrogen $(\mathrm{N})$, Phosphorous $(\mathrm{P})$, potassium $(\mathrm{K})$ were determined according to Jackson (1973).

- Nitrogen content

Total nitrogen was determined in digested plant material calorimetrically by Nessler's method (Chapman and Pratt, 1978).

- Phosphorus content

Phosphorus was determined by the Vanadomolyate yellow method as given by Jackson (1973).

- Potassium content (K)

Potassium was determined according to the method described by method Jackson (1973) using Beckman Flame photometer.

\section{C) Chemical properties of soil}

- Available nitrogen

The soil sample were extracted by $2 \mathrm{M} \mathrm{KCl} \mathrm{(1:20),} \mathrm{available} \mathrm{N}$ was determined according in soil extract by Micro Kjeldhal method (Bermner and Mulvaney, 1982).

- Available phosphorus

Available phosphorus was extracted with $0.5 \mathrm{M} \mathrm{NaHCO}_{3}$ solution adjusted to $\mathrm{pH} 8.5$ according to Olsen et al., (1954). Five $\mathrm{mL}$ of clear filtrate was taken in $100 \mathrm{~mL}$ volumetric flask and then added $5 \mathrm{~mL}$ color developing regent ascorbic acid molybdenum blue method. Reading was recorded on spectrometer (model SpectrAA-200) using $880 \mathrm{~nm}$ wave length Olsen's extraction method (Jackson, 1962). 


\section{- Available potassium}

The extraction was done by ammonium acetate $(1 \mathrm{~N}$ of $\mathrm{pH} 7.0)$ and potassium was determined according to (Jackson, 1962) by Jenway PFP-7 flame photometer.

\section{Statistical analysis}

All the data collected were subjected to statistical analysis of variance as described by Gomez and Gomez (1984). The treatment means were compared using L.S.D. test at 0.05 level of significant.

\section{Results and Discussion}

\section{A) Vegetative growth}

Results in Table (2) revealed that increasing in zeolite concentration up to $6 \%$ (240 g/pot) significantly increase of all vegetative growth characters i.e. (plant height $(126.62 \mathrm{~cm})$, fresh weight $(57.12 \mathrm{~g})$ and dry weight $(6.61 \mathrm{~g})$, total chlorophyll $(28.84 \mathrm{SPAD})$ and leaf area index $\left(218.65 \mathrm{~cm}^{2}\right)$, as compared with control treatment which recorded the lowest mean values of plant height $(75.81 \mathrm{~cm})$, fresh weight $(25.75 \mathrm{~g})$ and dry weight $(3.26 \mathrm{~g})$, total chlorophyll (22.45 SPAD) and leaf area index $\left(83.53 \mathrm{~cm}^{2}\right)$, whereas, urea fertilizer at $90 \mathrm{~kg} /$ fed. recorded the maximum values of plant height $(116.56$ $\mathrm{cm})$, fresh weight (48.62 g) and dry weight (5.40 g), total chlorophyll (27.67 SPAD) and leaf area index $\left(178.61 \mathrm{~cm}^{2}\right)$, as compared with untreated treatment (control) which gave the minimum values of plant height $(94.50 \mathrm{~cm})$, fresh weight $(34.56 \mathrm{~g})$ and dry weight $(3.98 \mathrm{~g})$, total chlorophyll (22.64 SPAD) and leaf area index $\left(126.77 \mathrm{~cm}^{2}\right)$, respectively, during 2019 season.

The interaction among zeolite levels and urea fertilizer was highly significant on plant height, was not significant on fresh, dry weight and leaf area index, but was significant on total chlorophyll (SPAD) during 2019 season.

Table 2: Vegetative growth of maize as affected by zeolite and urea fertilizers application during 2019 season.

\begin{tabular}{lccccc}
\hline \multicolumn{1}{c}{ Treatments } & $\begin{array}{c}\text { Plant height } \\
(\mathbf{c m})\end{array}$ & $\begin{array}{c}\text { Fresh } \\
\text { weight }(\mathbf{g})\end{array}$ & $\begin{array}{c}\text { Dry weight } \\
(\mathbf{g})\end{array}$ & $\begin{array}{c}\text { Total chlorophyll } \\
(\text { SPAD) }\end{array}$ & $\begin{array}{c}\text { LAI } \\
\left(\mathbf{c m}^{2}\right)\end{array}$ \\
\hline A) Zeolite & & & & & \\
Control & $75.81 \mathrm{~d}$ & $25.75 \mathrm{~d}$ & $3.26 \mathrm{~d}$ & $22.45 \mathrm{c}$ & $83.53 \mathrm{~d}$ \\
$2 \%$ & $97.81 \mathrm{c}$ & $35.19 \mathrm{c}$ & $3.97 \mathrm{c}$ & $24.12 \mathrm{~b}$ & $130.21 \mathrm{c}$ \\
$4 \%$ & $120.31 \mathrm{~b}$ & $47.37 \mathrm{~b}$ & $5.15 \mathrm{~b}$ & $24.84 \mathrm{~b}$ & $185.10 \mathrm{~b}$ \\
$6 \%$ & $126.62 \mathrm{a}$ & $57.12 \mathrm{a}$ & $6.61 \mathrm{a}$ & $28.84 \mathrm{a}$ & $218.65 \mathrm{a}$ \\
\hline LSD(0.05) & $\mathbf{3 . 0 2}$ & $\mathbf{3 . 1 7}$ & $\mathbf{0 . 5 5}$ & $\mathbf{1 . 3 6}$ & $\mathbf{2 6 . 8 3}$ \\
\hline B) Urea & & & & & \\
Control & $94.50 \mathrm{~d}$ & $34.56 \mathrm{~d}$ & $3.98 \mathrm{~b}$ & $22.64 \mathrm{c}$ & $126.77 \mathrm{c}$ \\
$30 \mathrm{~kg} /$ fed. & $101.00 \mathrm{c}$ & $38.62 \mathrm{c}$ & $4.44 \mathrm{~b}$ & $24.32 \mathrm{~b}$ & $145.42 \mathrm{bc}$ \\
$60 \mathrm{~kg} /$ fed. & $108.50 \mathrm{~b}$ & $43.62 \mathrm{~b}$ & $5.17 \mathrm{a}$ & $25.64 \mathrm{~b}$ & $166.69 \mathrm{ab}$ \\
$90 \mathrm{~kg} /$ fed. & $116.56 \mathrm{a}$ & $48.62 \mathrm{a}$ & $5.40 \mathrm{a}$ & $27.67 \mathrm{a}$ & $178.61 \mathrm{a}$ \\
\hline LSD(0.05) & $\mathbf{3 . 0 2}$ & $\mathbf{3 . 1 7}$ & $\mathbf{0 . 5 5}$ & $\mathbf{1 . 3 6}$ & $\mathbf{2 6 . 8 3}$ \\
\hline Interaction & & & & & \\
A $\times \mathbf{B}$ & $* *$ & $\mathbf{n s}$ & $\mathbf{n s}$ & & $\mathbf{n s}$ \\
\hline
\end{tabular}

Means in the same column followed by the same letter are statistically equalled according to LSD (0.05) probability level.

ns: not significant

*, * *: Significant at (0.05) and 0.01 level of probability, respectively.

These results were similar to Ashraf and Rehman (1999) who reported that increasing supply of $\mathrm{N}$ improved growth of corn. Ashraf et al. (2002) while assessing the effects of sub- and supra-optimal $\mathrm{N}$ regimes on wheat. It was also found that the dry matter production of wheat increased by increasing nitrogen levels. Khalid et al. (2003) working with rice, reported that plant growth was improved when urea $(\mathrm{N})$, potassium $(\mathrm{K})$ and phosphorus $(\mathrm{P})$ fertilizers were used. Robson and Deacon (1978) and Gastal and Saugier (1986) showed that urea application increases the leaf area of plants and canopies to greater extent than leaf and canopy photosynthesis. The relationship between $\mathrm{N}$ and leaf area index (LAI) depends on the pattern of biomass and $\mathrm{N}$ allocation to either photosynthetic leaf tissues or supporting 
structural tissues (stems), which is associated with differences in the intrinsic morphology of crops or genotypes. It is interesting to note that root growth was inhibited almost at all levels of urea application, which can be explained in view of Klemm (1966) who suggested that trade of photo-assimilates between shoots and roots is one of adaptive strategy in plants. Thus, in the present study, reduced root growth at higher urea application might have caused growth promotion of shoots. Nitrogen nutrition enhances metabolic processes that influence the physico-chemical environment at the soil root interface, modify the rhizospheric conditions, interact with cations and anions, and also enhance the activity of several enzyme systems (Fernandes and Rossiello, 1995).

\section{B) Chemical composition}

\section{Available NPK (\%) in leaves}

From the data presented in Table (3) it is clear that the nitrogen, phosphorus and potassium percentage in leaves was significantly affected by zeolite and urea treatments. The maximum nitrogen, phosphorus and potassium percentage in leaves was observed in increasing the zeolite treatment concentration up to $6 \%(3.26,0.39$ and $4.28 \%)$, while, the lowest nitrogen, phosphorus and potassium percentage in leaves was recorded in control treatment, $(1.76,0.19$ and $2.26 \%)$, respectively, during 2019 season.

In this respect, increasing urea fertilizer up to $90 \mathrm{~kg} /$ fed recorded the maximum nitrogen, phosphorus and potassium percentage in leaves $(3.04,0.40$ and $3.88 \%$ ), as compared with control treatment which gave the lowest mean values of nitrogen, phosphorus and potassium percentage in leaves $(1.48,0.21$ and $2.26 \%$ ),respectively, during 2019 season.

The interaction between zeolite levels and urea fertilizer was not significant on nitrogen and phosphorus percentage, but was highly significant on potassium percentage during 2019 season.

Ahmed et al. (2010) who also reported that zeolite amended with inorganic fertilizers enhanced uptake of $\mathrm{N}$ in maize. This observation can be comparable to the report of Gul et al. (2005), concerning to the use of zeolite to reduce the leaching of $\mathrm{K}$.

Table 3: NPK percentage of maize leaves as affected by zeolite and urea fertilizers application during 2019 season.

\begin{tabular}{lccc}
\hline \multicolumn{1}{c}{ Treatments } & $\mathbf{N}$ & $\begin{array}{c}\text { In leaves } \\
\mathbf{P}\end{array}$ & $\mathbf{K}$ \\
\hline $\mathbf{A})$ Zeolite & & & \\
0 & $1.76 \mathrm{c}$ & $0.19 \mathrm{c}$ & $2.26 \mathrm{c}$ \\
$2 \%$ & $1.94 \mathrm{c}$ & $0.29 \mathrm{~b}$ & $2.54 \mathrm{c}$ \\
$4 \%$ & $2.38 \mathrm{~b}$ & $0.31 \mathrm{~b}$ & $3.14 \mathrm{~b}$ \\
$6 \%$ & $3.26 \mathrm{a}$ & $0.39 \mathrm{a}$ & $4.28 \mathrm{a}$ \\
\hline $\mathbf{L S D}(\mathbf{0 . 0 5})$ & $\mathbf{0 . 3 1}$ & $\mathbf{0 . 0 4}$ & $\mathbf{0 . 3 6}$ \\
\hline $\mathbf{B})$ Urea & & & $2.26 \mathrm{~d}$ \\
0 & $1.48 \mathrm{~d}$ & $0.21 \mathrm{~d}$ & $2.84 \mathrm{c}$ \\
$30 \mathrm{~kg} /$ fed. & $2.24 \mathrm{c}$ & $0.25 \mathrm{c}$ & $3.22 \mathrm{~b}$ \\
$60 \mathrm{~kg} /$ fed. & $2.58 \mathrm{~b}$ & $0.32 \mathrm{~b}$ & $3.88 \mathrm{a}$ \\
$90 \mathrm{~kg} /$ fed. & $3.04 \mathrm{a}$ & $0.40 \mathrm{a}$ & $\mathbf{0 . 3 6}$ \\
\hline $\mathbf{L S D}(\mathbf{0 . 0 5})$ & $\mathbf{0 . 3 1}$ & $\mathbf{0 . 0 4}$ & $* *$ \\
\hline Interaction & & & $\mathrm{ns}$ \\
$\mathbf{A} \times \mathbf{B}$ & $\mathrm{ns}$ & & \\
\hline
\end{tabular}

Means in the same column followed by the same letter are statistically equalled according to LSD (0.05) probability level.

ns: not significant

$*, * *$ : Significant at $(0.05)$ and 0.01 level of probability, respectively.

\section{C) Chemical properties of soil}

\section{Available NPK in soil}

Data presented in Table (4) clearly reveals that the available NPK in soil was significantly affected by various treatments. The maximum available NPK in soil was observed in the zeolite 
treatment concentration up to $6 \%(29.47,88.31$ and $732.81 \mathrm{mg} / \mathrm{kg})$, while, the lowest available nitrogen, phosphorus and potassium in soil was recorded in control treatment $(13.32,37.37$ and $564.06 \mathrm{mg} / \mathrm{kg}$ ), respectively, during 2019 season.

In this respect, increasing urea fertilizer up to $90 \mathrm{~kg} /$ fed recorded the maximum nitrogen, phosphorus and potassium percentage in soil $(27.37,75.16$ and $732.81 \mathrm{mg} / \mathrm{kg})$, as compared with control treatment which gave the lowest mean values of nitrogen, phosphorus and potassium percentage in soil $(18.63,54.31$ and $607.81 \mathrm{mg} / \mathrm{kg}$ ), respectively, during 2019 season.

The interaction between zeolite levels and urea fertilizer was not significant on available nitrogen, phosphorus and potassium in soil, during 2019 season.

Table 4: NPK available in soil as affected by zeolite and urea fertilizers application during 2019 season.

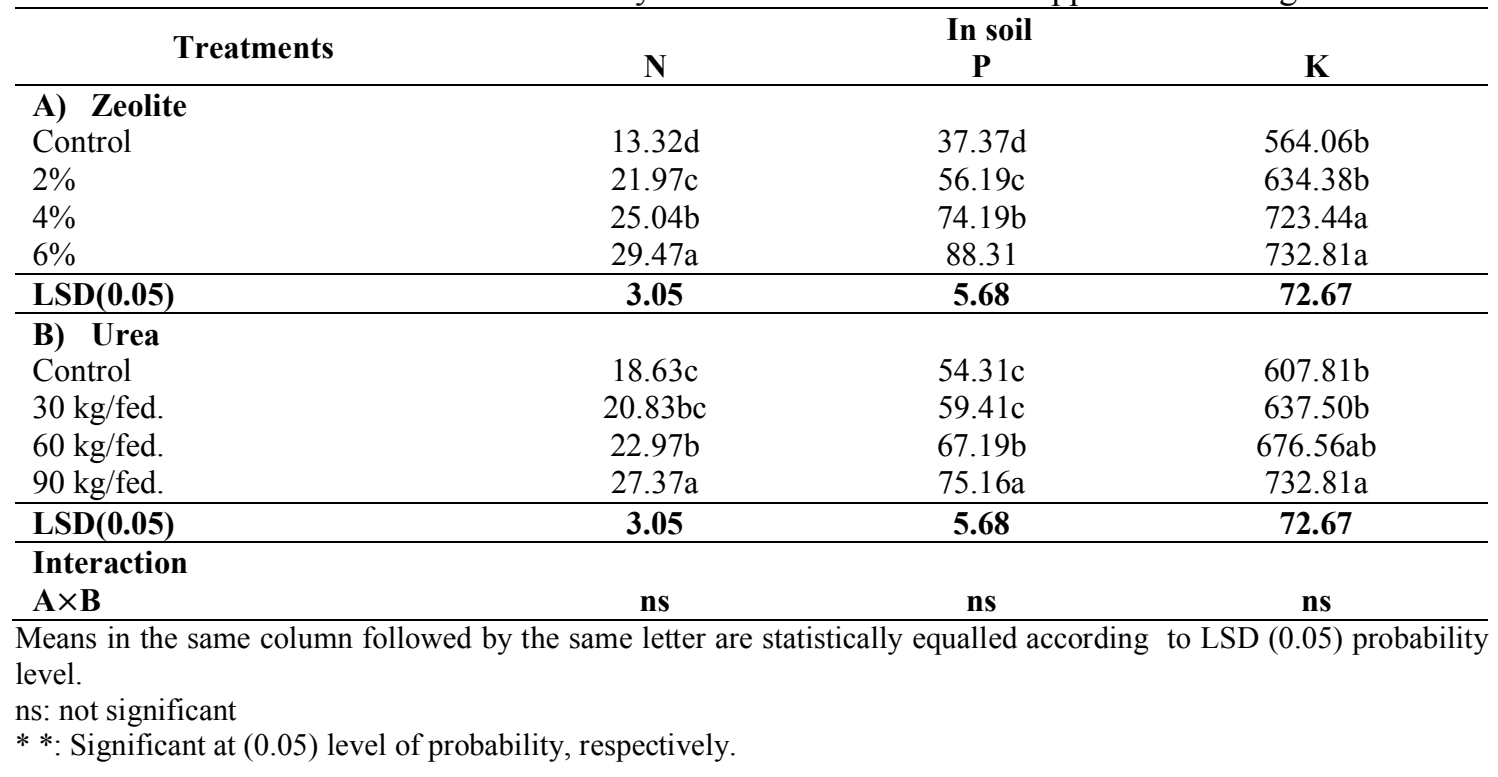

\section{References}

Ahmed, O. H., G. Sumalatha and A.M.N. Muhamad, 2010. Use of zeolite in maize (Zea mays) cultivation on nitrogen, potassium and phosphorus uptake and use efficiency. Int. J. Phys. Sci., 5(15): 2393-2401.

Al-Busaidi, A., T. Yamamoto, M. Inoue, A. E. Eneji, Y. Mori and M. Irshad, 2008. Effects of zeolite on soil nutrients and growth of barley following irrigation with saline water. J. Plant Nut., 1-12

Ashraf, M. and H. Rehman, 1999. Interactive effects of nitrate and long-term water logging on growth, water relations, and exchange properties of maize (Zea mays, L). Plant Sci. 144: 35-43.

Ashraf, M., M.A. Mushtaq and A. Nisar, 2002. Effect of sub and supra-optimal nitrogen regimes on nutrient relation in two spring wheat cultivars differing in salinity tolerance. Flora, 197: 126-133.

Behzadfar, M., S.H. Sadeghi, M.J. Khanjani and Z. Hazbavi, 2017. Effects of rates and time of zeolite application on controlling runoff generation and soil loss from a soil subjected to a freeze-thaw cycle. Int. Soil \& Water Conser. Res., 5(2): 95-101.

Bernardi, A.C. C., S. Souza, R.D. Cardoso and P.P.A. Oliveira, 2007. Ammonia volatilization, dry matter yield and nitrogen levels of Italian ryegrass fertilized with urea and zeolite. Embrapa Pecuária Sudeste-Artigoemanais de congresso (ALICE). World Congress of Soil Sci., 19.

Bernardi, A.C. De C. P.R.P. Paiva, M.B. De M. Monte, 2007. Produção de matéria seca e teores de nitrogênio em milho para silagem adubado com uréia misturada a zeólita. São Carlos: Embrapa Pecuária Sudeste, (Embrapa Pecuária

Bremner, J.M. and C.S. Mulvaney, 1982. Methods of soil analysis, part 2 chemical and microbiological properties, 595-624. 
Calvo, B., L. Canoira, F. Morante, J.M. Martínezbedia, C. Vinagre and J. E.García-González, J. Elsen and $\mathrm{R}$. Alcantara, 2009. Continuous elimination of $\mathrm{Pb}^{2+}, \mathrm{Cu}^{2+}, \mathrm{Zn}^{2+}, \mathrm{H}^{+}$and $\mathrm{NH}^{4+}$ from acidic waters by ionic exchange on natural zeolites. J. Hazardous Materials, 166: 619-627.

Cantarella, H., P.C.O. Trivelin, T.L.M. Contin, F.L.F. Dias, R. Rosseto, R. Marcelino, R.B. Coimbra and J.A. Quaggio, 2008. Ammonia volatilisation from urease inhibitor-treated urea applied to sugarcane trashblankets. Scientia Agricola, 65: 397-401.

Chapman, H. D. and P.F. Pratt, 1978. Method of Analysis for Soil and Water. $2^{\text {nd }}$ Ed., Chapter, 17pp 150-161. Uni. Calif. Div. Agric. Sci. USA.

Chien, S.H., L.I. Prochnow and H. Cantarella, 2009. Recent developments of fertilizer production and use to improve nutrient efficiency and minimize environmental impacts. Adv. Agron., 102: $267-$ 322.

Fahad, S., S. Hussain, A. Matloob, F.A. Khan, A. Khaliq, S. Saud, S. Hassan, D. Shan, F. Khan, N. Ullah, M. Faiq, M.R. Khan, A.K. Tareen, A. Khan, A. Ullah, N. Ullah, and J. Huang , 2014.Phytohormones and plant responses to salinity stress: a review. Plant Growth Reg., 75: 391404.

Fernandes, M.S. and R.O.P. Rossiello, 1995. Mineral nitrogen in plant physiology and plant nutrition. Crit. Rev. Plant Sci. 14: 11-48.

Gastal, F. and B. Saugier, 1986. Alimentation azotee et croissance de Ia fetuque elevee. I. Assimilation du carbone et repartition entre organs. Agron. 6: 157-166.

Ghanbari, M. and S. Ariafar, 2013. The effect of water deficit and zeolite application on growth traits and oil yield of medicinal peppermint (Mentha piperita L.). Int. J. Med. Arom. Plants, 3(1): 33-39. 15 .

Gomez, K. A. and A. A. Gomez, 1984.Statistical Procedures for Agricultural Research.John Wiley and Sons. Inc., New York.

Gul, A., D. Erogul and A. R. Ongun, 2005. Comparison of the use of zeolite and perlite as substrate for crisp-head lettuce. Sci. Hort., 106:464-471.

Heffer, P. and M. Prud'homme, 2015. Fertilizer Outlook 2015- 2019. Paris: IFA, 2015. $83^{\text {rd }}$ IFA Annual Conference Istanbul (Turkey), 25-27 May 2015.

Jackson, M.L., 1962. Chemical composition of soil In F.E. Bean (Ed).

Jackson, M.L., 1973.Soil Chemical Analysis. Prentice-Hall of Englewood Clifs, New Jersy, pp: 925.

Jakab, S. and A. Jakab, 2010. Efects of the Zeolitic Tuf on the physical characteristics of Haplic Luvisol and the quality of fruits on apple orchards. Agric. Enviro., 2:31-37

Khalid, M., F.M. Chaudhry and H. Abid, 2003. Effect of different levels of NPK on the yield and quality of Rice cv. IR-6. J. Res. Sci., 14: 11-15.

Klemm, K., 1966. Der Einfluss der N-Form auf die Ertragsbildung verschiedener Kulturpflanzen. Bodenkultur, 17: 265-284.

Lija, M., A. O. Haruna and S. Kasim, 2014. Maize (Zea mays L.) nutrient use efficiency as affected by formulated fertilizer with Clinoptilolite Zeolite. Emir. J. Food Agric., 26 (3): 284-292.

Lowther, G. R., 1980. Using of single $\mathrm{H}_{2} \mathrm{So}_{4}-\mathrm{H}_{2} \mathrm{O}_{2}$ digest for the analysis of pinusrediataneedles. Common Soil Sci. Plant Analysis, 11: 175- 188.

Najafi-Ghiri, M., 2014. Effects of zeolite and vermicompost applications on potassium release from calcareous soils. Soil \& Water Res., 9: 31-37.

Nascimento, C.A.C., D.G.C. Vitti, L. De A. Faria, P.H.C. Luz and F.L. Mendes, Ammonia volatilization from coated urea forms. Revista Brasileira de Ciência do Solo, 37:1057-1063.

Oliveira, J. I. P., D. K. Krysczun, C. Ubessi, T. Olivoto, B. Giacomini Sari, M. I. Diel, A. D. Lúcio and L. V. Viau, 2017.The effect of types and split of urea on yield indicators and yield components of maize. Aust. J. Crop Sci., 11(12):1594-1598.

Olsen, S., C.Cole, F. Watanabe and L. A. Dean, 1954.Estimation of available phosphorus in soils by extraction with sodium bicarbonate.U.S.D.A Circular No.939.on growth and yield of maize. West Africa J. Appl. Ecol., 9: 1-11.

Ramos, F. T., O. L. S. Weber, E. B. Morais, E. F. G. C. Dores, Z. M. Lima and J. M. P. Novais , 2018. Physical, chemical, and microbiological evaluation of a compost conditioned with zeolites. Afri. J. Agric. Res., 13(14): 664-672. 
Robson, M.J. and M.J. Deacon, 1978. Nitrogen deficiency in small closed communities of S 24 ryegrass. II. Changes in the weight and chemical composition of single leaves during their growth and death. Ann. Bot. 42: 1199-1213.

Rochette, P., D.A. Angers, M.H. Chantigny, M. O. Gasser, J.D. Macdonald, D.E. Pelster and N. Bertrand, 2013. $\mathrm{NH}_{3}$ volatilization, soil $\mathrm{NH}_{4}{ }^{+}$concentration and soil $\mathrm{pH}$ following subsurface banding of urea at increasing rates. Canadian J. Soil Sci., 93: 261-268.

Soares, J.R., H. Cantarella and M.L. De C. Menegale, 2012. Ammonia volatilization losses from surface-applied urea with urease and nitrification inhibitors. Soil Biol. \& Bioch., 52: 82-89.

Sudeste. Comunicado técnico, 77).

Suriyaprabha, R., G.K. Rathinam, Y.P. Prabu, V. Rajendran and N. Kannan, 2014. Effect of silica nanoparticles on microbial biomass and silica availability in maize rhizosphere. Biotech. Appl. Biochem., https ://doi.org/10.1002/bab.1191

Tandon, H., 1995. Methods of Analysis of soil, plants, waters and ferilizer, p: 144. Fertilizers development and consultation organization, New Delhi, India.

Trenkel, M.E., 2010. Slow and controlled release and stabilized fertilizers: an option for enhancing nutrient use efficiencyin agriculture. $2^{\text {nd }}$ ed. Paris: Int. Fertilizer Industry Association, 160p.

Zahedi, H. and H. R. Tohidi-Moghadam, 2011. Effect of drought stress on antioxidant enzymes activities with zeolite and selenium application in canola cultivars. Research on crops 12 (2): 388392. 